\title{
Current incidence and trends in marital breakdown
}

\author{
Robert Chester \\ B.Sc.(Econ.) \\ Department of Social Administration, The University, Hull
}

\section{Introduction}

Between 1959, the post-war low-point, and 1970, the final year of the old divorce law, the annual number of petitions for legal termination of marriage in England and Wales almost trebled, and the rate more than doubled. The absolute rise was from 26,000 petitions in 1959 to 72,000 petitions in 1970 , and the trend, if anything, was tending to steepen rather than to decline. Even at 1970 rates some four and a half million adults will experience divorce during the remaining three decades of this century, more than twice the number of those with such experience in the previous 100 years. Such figures depict a contemporary mass phenomenon of considerable social importance, and some observers have deduced from them a substantial decline in the stability of marriage. Unless, however, marital stability is to be measured by the mere maintenance of the legal tie, such a conclusion goes somewhat beyond existing evidence. Marital breakdown is a complex entity which, for reasons relating both to definition and recording, is not currently susceptible to accurate quantification. Divorce is but one course of action open to those whose marriages fail, and it is not known how far divorce statistics may serve as an index of marital disruption.

\section{Marriage breakdown}

In discussing family disorganization Goode (1966) noted two elements which together might be conceived as constituting marriage breakdown, viz.

(a) 'Empty shell' marriages, where cohabitation persists, but with little meaning for the partners and with minimal or negative mutual affective support. Marriages, that is, which are socially and legally existent but so marked by disharmony or indifference that they must be counted as broken down.

(b) Willed terminations, either mutual or through unilateral volition, via divorce, annulment, separation or desertion. Marriages, that is, which have broken up as well as broken down, whether or not the legal nexus is intact.

It will be self-apparent that category (a) above presents definitional problems, and it will be shown that category (b) is resistant to measurement because some of its components are labile, and not all are manifested in public records. Figure 1 attempts to

give diagrammatic representation to the components of marriage breakdown and to illustrate the difficulties of measuring its incidence. This diagram is not intended to chart the process of marriage breakdown, but rather to show the differentiation of all marriages into those which do and those which do not experience breakdown in some sense.

FIG. 1.

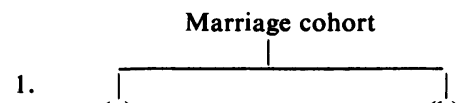

(a)

Not experiencing marital difficulties

2.

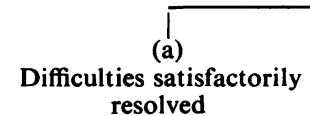

3.

4.

5.



The minimum measure of marriage breakdown must be the figures for $3 \mathrm{~b}$, those marriages which break up. To this total many would wish to add those couples remaining together only in protracted disharmony or mutual indifference, and it is here that problems of definition occur. To include all marriages which fall short of current ideals of marital success would be to manufacture breakdown by imposing standards which perhaps only a minority of couples could satisfy. Marital difficulties are widespread in modern society (Pierce, 1963), and 
there are many possible types and levels of resolution of such difficulties. The allocation of couples from $1 \mathrm{~b}$ between $2 \mathrm{a}$ and $\mathrm{b}$ would thus depend upon whose view-point was taken and what standards were applied. If agreement were reached on a definition of $2 b$ we might regard those falling therein as constituting the marriage breakdown group, but even approximate quantification would still be beyond us because we have very little usable information in this area. Chesser (1956) reported that approximately $6 \%$ of his sample of married women defined themselves as unhappily or very unhappily married, and Pierce (1963) found that of those married for less than 10 years $4 \%$ had either experienced a period of separation or had contemplated separating. In the former case, however, even some of the unhappily married did not regret their marriages, and in the latter we have no data on eventual outcome. Turner (1969) suggests a figure of between 5 and $10 \%$ for 'empty shell' marriages and informal separations combined, but this is on 'very slender evidence'. In practice almost nothing can be said about marriage breakdowns which do not eventuate in some form of breakup, and discussion of incidence has to be restricted to Goode's second category, willed terminations (shown at $3 \mathrm{~b}$ in the diagram). The marriages at $3 \mathrm{a}$ might perhaps be called failed marriages to distinguish them from terminated marriages, the two together indeterminately comprising marriage breakdown.

\section{Terminated marriages}

Even with attention restricted to terminated marriages, it is self-evident from the diagram that the divorce figures at $5 \mathrm{~b}$ portray only part of the total. Termination takes several forms, and while some can be measured others cannot even be estimated with confidence. The principal forms of termination are divorce, annulment, and the several types of separation, and each is briefly commented upon below.

\section{(i) Divorce}

This is the total dissolution of a marriage, leaving the partners free to remarry. Numbers are accurately known, but the official statistics are uninformative in some respects and the dearth of academic investigation in Britain means that there are many gaps in our knowledge of the characteristics of divorcing couples.

\section{(ii) Annulment}

Technically this declares a marriage contract to be invalid rather than terminated. Although the distinction is theologically and legally significant its social importance is less clear. Nullity is anyway statistically unimportant relative to divorce (1086 in 1970), and for convenience the subsequent discus- sion follows common practice in totalling annulments with divorces for numerical analysis.

\section{(iii) Separation}

This term is used here to describe the situation where a marriage is socially defunct although legally intact. The spouses may have parted through mutual or unilateral decision, and may be cohabiting with alternative partners, but they are still husband and wife. There are several forms of separation, and each is worth noting.

(a) Judicial separation. Granted by the higher courts, this corresponds to the ecclesiastical divorce a mensa et thoro. Statistically such actions are thoroughly insignificant and may safely be ignored.

(b) Magistrates' orders. These cannot be ignored because currently applications exceed 30,000 per annum. Colloquially they are referred to as separation orders, but technically this misrepresents their nature and they are more helpfully thought of as maintenance orders. Annual information is provided, but for reasons to be discussed there are limitations on its usefulness.

(c) Informal separations. Many couples part without recourse to law, and thus cannot be counted. Some may arrange private legal settlements, but almost certainly most do not, and even speculative estimates are hard to make. These cases are primarily responsible for uncertainty about the total number of terminated marriages.

It must be appreciated that the terminated marriages appearing at $5 \mathrm{~b}$ in the diagram are the only ones we can measure with certainty. This is partly because of the unknown number of informal separations, but also because we can derive only limited help from the statistics of magistrates' proceedings. Firstly, many such actions are repetitions of earlier actions in respect of the same marriage rather than newly notified marriage breakdowns. Furthermore, no court action is required to cancel such orders if the couple become reconciled, and many orders are effectively dead soon after issue. Again, a higher proportion of applications is withdrawn or unsuccessful than is the case with divorce, and we know little about applications not resulting in an order. And finally, the supplementary information about couples separating in this way is very scant indeed, although some gaps have recently been filled by McGregor, Blom-Cooper \& Gibson (1970).

A further vital point to be made about the various categories of termination other than divorce or nullity is that none is necessarily an ultimate condition. Informal separations frequently precede court action, and magistrates' proceedings are often an interim step to divorce. McGregor et al. (1970) suggest that perhaps a half of those with maintenance orders go on to divorce, and clearly many informal 
separations ultimately become divorces. Moreover, the interval from breakup to divorce is normally lengthy, ranging up to and exceeding 30 years (Chester, 1971a). Measurement of numbers currently in given situations, therefore, would not indicate ultimate outcomes, and simple totalling would lead to double counting (Chester, 1971b). The fact that the components of terminated marriage are not permanently discrete means that we do not have a satisfactory measure of total marital termination for any of even the most statistically sophisticated societies (Goode, 1962). If, as seems possible, discordant couples are more frequently turning to divorce as a solution, then divorce figures will afford an increasingly more accurate index of the extent of marriage breakdown. Meanwhile, great caution must be excercised in extrapolating from divorce trends to marriage breakdown more generally.

Such agnosticism, however, does not invalidate the study of divorce trends, since this study is both interesting in its own right and informative on the state of marriage. The recent rapid and continuous rise in divorce is indicative of changes in marriage behaviour, and probably in the values surrounding marriage in contemporary conditions. The remainder of this paper, therefore, will primarily be concerned with the current prevalence of divorce, some recent trends, and some modest epidemiological analysis.

\section{The incidence of divorce}

For many purposes it is preferable to deal with petitions for divorce rather than decrees granted, because the latter are liable to perturbation by administrative changes which obscure the trend (General Register Office, 1946-50), and because a failed petition nevertheless represents a broken marriage. Petitioning reached its historical peak in 1947, and then declined throughout the 1950s, attaining its post-war low-point in 1959. Thereafter, the numbers grew by an annual average of almost $10 \%$, achieving a total increase of $172 \%$ in 11 years. Annual numbers are shown in Table 1, where it can be seen that the rising trend was relatively constant, and that the main eccentricity was a particularly sharp rise of $17 \%$ in 1970 . At present, this apparent leap in the growth rate is difficult to interpret, but it is possible that the new divorce law (effective from 1 January 1971) had some retrospective influence. It is now possible for a 'guiltless' spouse to be unwillingly divorced after 5 years of separation, and it may be that some individuals who had been withholding a divorce from a 'guilty' spouse took preemptive action in 1970, thus swelling numbers beyond what would be expected on the trend. It is possible also that widespread public discussion of divorce throughout 1969 and 1970 stimulated some individuals to institute proceedings earlier than might otherwise have been the case.

The first year of the new law was expected to bring a marked increase in petitions, and provisional estimates suggest that the increase in fact was of the order of $50 \%$. The ultimate effect of the new law is as yet uncertain, although it seems likely to produce an increase in divorce both because it widens opportunity and because in modifying the adversary style of litigation it permits 'civilized' divorce. On previous experience of legislative reforms it is likely that numbers will fall back after the accumulated backlog is worked through, although remaining higher than before the reform. Certainly it will be some time before the 'bulge' created by the new legislation can be distinguished from any continuing trend to increased divorce.

Absolute numbers have a use in measuring the importance of divorce, but they may be misleading unless related to a relevant exposed population to produce a rate. Such a rate is officially provided, and the recent figures are shown in Table 1 . It should be noted that the rate is based upon decrees rather than petitions, and that the petitioning rate would be higher. The rate increased by $135 \%$ between 1959 and 1970, a figure somewhat lower than that for the increase in petitions thus indicating the need for caution in responding to absolute numbers. Nevertheless, the rate does show a sharp rise, and this rise does not seem susceptible to the type of explanation

TABLE 1. Petitions filed for divorce and nullity and divorce rates/1000 married population: England and Wales (source: Registrar General)

\begin{tabular}{cccccc}
\hline Year & $\begin{array}{c}\text { Petitions } \\
\text { filed }\end{array}$ & $\begin{array}{c}\text { Divorce } \\
\text { rate }\end{array}$ & Year & $\begin{array}{c}\text { Petitions } \\
\text { filed }\end{array}$ & $\begin{array}{c}\text { Divorce } \\
\text { rate }\end{array}$ \\
\hline 1947 & 48,501 & - & 1965 & 42,981 & $3 \cdot 1$ \\
1959 & 26,327 & $2 \cdot 1$ & 1966 & 46,609 & $3 \cdot 2$ \\
1960 & 28,542 & $2 \cdot 0$ & 1967 & 50,956 & $3 \cdot 5$ \\
1961 & 31,905 & $2 \cdot 1$ & 1968 & 55,007 & $3 \cdot 7$ \\
1962 & 34,615 & $2 \cdot 4$ & 1969 & 61,216 & $4 \cdot 1$ \\
1963 & 37,304 & $2 \cdot 7$ & 1970 & 71,661 & $4 \cdot 7^{*}$ \\
1964 & 41,468 & $2 \cdot 9$ & & & \\
\hline
\end{tabular}


which has hitherto been offered for the historical increase in divorce. Apologists for the contemporary family, such as McGregor (1957) and Fletcher (1966), and also more neutral writers, such as Rowntree \& Carrier (1958), have interpreted divorce trends up to the 1950 s primarily in terms of demographic changes, the disturbing effects of war, and the increased availability of divorce as a remedy brought about by legislative reform and legal aid provision. Such explanations fit the historical facts and seem plausible, but it is difficult to see how they might explain the recent rapid rise in petitioning. In an apparent reluctance to look elsewhere than to increased availability to explain higher divorce levels some observers (e.g. McGregor et al., 1970) have been led to exaggerate the importance of legal aid. It has been shown, however, that the hypothesis which sees legal aid as a major factor in contemporary divorce demand does not fit the evidence, and that recent trends must spring from other and more fundamental causes than modifications to a limited welfare scheme (Chester, 1972a). It is more probable that current divorce statistics are reflecting normative changes related to the new social conditions which have developed throughout the post-war years (Chester, 1971b). The analysis of contemporary divorce is in part a study of social change, and some further investigation of recent divorce behaviour is warranted.

\section{Cohort analysis}

Additional insight into generational changes in behaviour can be given by the method of cohort analysis (see Ryder, 1965). Period divorce rates (as displayed in Table 1) can be misleading as indicators of trends because they respond to temporary or unique events, such as law reforms, wars, and economic fluctuations. Such rates have practical and theoretical utility, but they do not reveal generational behaviour patterns because the divorces of any one year occur within marriages of many different durations. Cohort analysis utilizes a more refined notion of the population at risk, and reflects generational changes with considerable sensitivity (Ferris, 1970; Rowntree \& Carrier, 1958). The divorce experience of marriage peers can be cumulated as they move through time and this experience can be compared for a succession of cohorts at equivalent intervals from marriage. Calculations of the cumulative divorce experience of the annual marriage cohorts from 1960 onwards are shown in Table 2, which also includes the figures for the marriages of 1942-43. The latter group is included because it had the most extreme divorce figures in history for durations up to $\mathbf{1 0}$ years, and because war-time marriages were widely supposed to be peculiarly vulnerable to breakdown.

For inter-cohort comparisons readings should be made down the columns, and it can be seen that not only are successive cohorts experiencing a higher incidence of divorce at given durations, but also that even the lowest figures are greater than those for the war-time marriages. Unfortunately the series is short, and will be disturbed in the future by the consequences of the new legislation, but the trend is clearly visible. The universal tendency for each successive cohort at any given duration is upward, and there is no sign of levelling off.

In seeking to interpret the above data, three questions in particular seem worth pursuing, viz.

(i) Are contemporary couples divorcing more, or merely divorcing earlier?

(ii) If divorcing more, are contemporary couples experiencing more marriage breakdown, or merely resorting more readily to divorce in the event of breakdown?

(iii) If experiencing more breakdown or more divorce, is this a temporary phenomenon or is it a new pattern related to contemporary social conditions?

These questions have been approached elsewhere (Chester, 1971b), and it was concluded that contemporary couples are almost certainly having more

TABLE 2. Percentage of successive marriage cohorts divorced by stated legal durations of marriage (source: Registrar General and Rowntree \& Carrier (1958))

\begin{tabular}{|c|c|c|c|c|c|c|c|c|}
\hline \multirow{2}{*}{$\begin{array}{l}\text { Marriage } \\
\text { cohort }\end{array}$} & \multicolumn{8}{|c|}{ Duration of marriage (completed years) } \\
\hline & 3 & 4 & 5 & 6 & 7 & 8 & 9 & 10 \\
\hline $\begin{array}{l}1960 \\
1961 \\
1962 \\
1963 \\
1964 \\
1965 \\
1966 \\
1967\end{array}$ & $\begin{array}{l}0 \cdot 14 \\
0.15 \\
0.17 \\
0 \cdot 16 \\
0 \cdot 18 \\
0.22 \\
0 \cdot 25 \\
0 \cdot 27^{*}\end{array}$ & $\begin{array}{l}0.70 \\
0.76 \\
0.85 \\
0.95 \\
1.03 \\
1.19 \\
1.39^{*}\end{array}$ & $\begin{array}{l}1.54 \\
1.62 \\
1.80 \\
2.00 \\
2.20 \\
2.55^{*}\end{array}$ & $\begin{array}{l}2 \cdot 37 \\
2 \cdot 52 \\
2 \cdot 73 \\
3 \cdot 10 \\
3 \cdot 43^{*}\end{array}$ & $\begin{array}{l}3 \cdot 22 \\
3 \cdot 38 \\
3 \cdot 73 \\
4 \cdot 25^{*}\end{array}$ & $\begin{array}{l}4 \cdot 05 \\
4 \cdot 35 \\
4 \cdot 75^{*}\end{array}$ & $\begin{array}{l}4 \cdot 89 \\
5 \cdot 33^{*}\end{array}$ & $5 \cdot 75^{*}$ \\
\hline $1942-43$ & - & - & 1.08 & 1.98 & $2 \cdot 75$ & 3.44 & $4 \cdot 01$ & $4 \cdot 64$ \\
\hline
\end{tabular}

* Unofficial figures. 
divorce as well as earlier divorce; that they are probably experiencing more marriage breakdown, although not as much as is suggested by divorce figures above; and that high manifest levels of marital instability should be expected to become a normal feature of social experience. It is possible that between one-sixth and one-quarter of those currently marrying will experience marriage breakdown through termination or internal collapse of the relationship. This forecast is highly tentative, as any forecast must be after two decades in which petitioning has first halved and then doubled. Nevertheless, it is difficult to find any theoretical reason or empirical evidence to suggest that the recent upward trend is due for reversal. It is also very difficult to find support for the notion that the contemporary increase in divorce is merely at the expense of informal separations, and therefore represents a public manifestation of levels of marriage breakdown that already existed covertly. The magnitude of the recent increase in divorce requires that for this hypothesis to be true, the level of informal separation in, say, 1959, was very high, and indeed greater than the level of recorded breakdown. The thesis must also assume that the shift from private to legal termination has been at a very rapid rate, and no explanation of this has been advanced. Furthermore, there is some indirect evidence which suggests that the rate of informal termination may also be increasing. Table 3 shows that whereas matrimonial proceedings in local courts have remained almost constant over the past decade, the number of women in receipt of national assistance (until 1965) or supplementary benefit (since 1966) has increased regularly and markedly. Some of these recipients have court orders, but about $50 \%$ have not, and a further $11 \%$ or so have private out-of-court arrangements (i.e. about $60 \%$ represent informal breakdowns). The lower row in the table suggests, if anything, an increase in informal separations recently. Although it is necessary to say that the adequacy of these figures as an index of informal termination is unproved, such data give no support to the thesis that marriage breakdown is merely being redistributed through its various categories. All the evidence suggests that in recent years there has been a real rather than an illusory increase in marital disruption, and those who deny this must produce more than simple assertion in support of their denial.

\section{The duration of marriage}

A supplementary measure of the stability of marriage is provided by its temporal endurance, but here, too, there are gaps in our knowledge. Many secondary commentators follow McGregor (1957) in pointing out that some $60 \%$ of dissolved marriages have endured at least 10 years, while approximately $20 \%$ have lasted more than 20 years. In fact, there has been a tendency in the last decade for divorces to occur sooner after marriage, although this does not seriously invalidate the point that a high proportion of divorces occur after appreciable durations of marriage. This fact is commonly used to deny the charge of moral pessimists that modern couples are more 'divorce-minded' than their predecessors, and fail to give their marriages adequate opportunity to work.

The use of duration data in this way, however, ignores the fact that the public and private reality of marriage is symbolized and made effective by cohabitation, and in the natural history of marriage breakdown it is the cessation of cohabitation which is the most significant and traumatic step for those concerned (Chester, 1971c). However it comes about, separation is a most important 'psycho-social transition' (Murray-Parkes, 1971), and for many purposes what we need to know is the de facto duration of marriage (from wedding to breakup) rather than de jure duration (wedding to decree absolute). Newly available data for this country (Chester, 1971a) confirm American experience that reliance on legal durations can misrepresent the facts about marital disruption.

Table 4 displays information derived from the court records of $\mathbf{8 0 5}$ divorces arising from bachelorspinster marriages (often called primary marriages). For these cases the effective duration of marriage was markedly briefer than the legal duration, and it is clear that marriages characteristically break up much earlier than the official statistics reveal. Nearly $40 \%$ here were effectively ended in the first quinquennium, against only $16 \%$ divorced in this period. More detailed inspection of the data reveals that separations reached their peak in the third year of

TABle 3. Applications to Magistrates' Courts (England and Wales), and separated women in receipt of national assistance or supplementary benefit (Great Britain)

\begin{tabular}{|c|c|c|c|c|c|c|c|}
\hline & 1957 & 1959 & 1961 & 1963 & 1965 & 1967 & 1969 \\
\hline $\begin{array}{l}\text { Court } \\
\text { applications }\end{array}$ & 32,994 & 33,047 & 32,536 & 31,157 & 32,464 & 32,095 & 32,433 \\
\hline $\begin{array}{l}\text { Receipt of } \\
\text { assistance }\end{array}$ & 68,000 & 77,000 & 84,000 & 102,000 & 104,000 & 148,000 & 161,000 \\
\hline
\end{tabular}


marriage, some 2 years before the peak of divorces, and that the most hazardous years lay between the first and fourth anniversaries of the wedding, where a quarter of the separations occurred. Approximately one in seven $(14 \%)$ occurred within the first 2 years, and it has been shown that this group of only briefly-enduring marriages possessed some special characteristics, principally youth, premarital pregnancy, and greater use of desertion as a ground (Chester, 1972b).

Duration-data can be otherwise presented, as in Table 5, which shows mean and median figures for the two kinds of duration. Here the finding is that the difference between the mean de facto and de jure durations was 4.6 years, with a comparable difference for the medians. Confidence in the representative nature of the local figures reported here is increased by two recently published pieces of information. The Registrar General's annual review gives a mean legal duration of $13 \cdot 1$ years for all primary-marriage divorces in 1966, a figure which compares reasonably with that reported in the table. In addition, $\mathrm{McGregor}$ et al. (1970) found a mean delay of 5 years from magistrates' court action to divorce, and this interval corresponds roughly to the difference between de facto and de jure duration. It will, of course, be appreciated that the mean figures conceal variation. Nevertheless, the detailed distribution shows that in two-thirds of cases there was a delay of at least 2 years between breakup and divorce, that a third of the intervals were greater than 4 years, and that the median was 2.9 years. Although people may divorce in order to remarry, it seems that they may not so commonly break up to do so, or at least that petitioners are in no hurry after separation to be legally free.

The information above casts a different light upon the periods of maximum vulnerability of marriage from that which is provided by divorce statistics based upon legal durations, and such findings may have implications for supportive policy. Consistent with American data (e.g. Monahan, 1962), it is the earliest years which are most critical for the stability of marriage, even though there is a secondary peak of divorces at durations approaching 20 years. As will be indicated, the early years are particularly vulnerable in the case of youthful marriages, and this vulnerability may be increasing. In addition, data on de facto duration are pertinent to analysis of the comparative fertility of divorcing and nondivorcing couples, and this will be alluded to below.

\section{Age at marriage}

It is well-known that age at marriage is inversely related to divorce. This has been established crossnationally, as has the modern tendency for the numbers and proportions of young marriages to increase (Moss, 1965). British official statistics have repeatedly shown that marriages where the bride is under 20 years at marriage are at enhanced risk of divorce, and that the risk is even greater when both spouses are teen-aged. The Registrar General's 1966 commentary includes forecasts based on age-atmarriage divorce rates for marriages of the 1960s which indicate that divorce probability is consistently twice as high for brides under 20 as for those aged 20-24. The fate of recent teen-aged marriages can be discerned by the construction of cohort tables similar to that shown above for all marriages, and the appropriate calculations are shown in Tables 6 and 7.

It is evident that the developing pattern matches that for all marriages shown in Table 2, although with higher proportions divorced for the two groups here under review. Where the bride alone was teenaged, $9 \%$ of the 1960 marriages had been dissolved before the tenth anniversary. With both spouses under 20 the corresponding figure was $13 \%$, and

TABle 4. Percentage distribution of marriage durations in grouped years (nearest 1\%) (source: Chester 1971 a)

\begin{tabular}{lcccc}
\hline & \multicolumn{5}{c}{ Durations in years } \\
\cline { 2 - 5 } & $0-5$ & $5-10$ & $10-20$ & Over 20 \\
\hline De jure durations & 16 & 29 & 33 & 22 \\
De facto durations & 38 & 24 & 28 & 10 \\
\hline
\end{tabular}

TABle 5. Primary marriages-mean and median durations in years $(N=805)$ (source: Chester 1971a)

\begin{tabular}{lccccc}
\hline & \multicolumn{2}{c}{ Mean durations } & & \multicolumn{2}{c}{ Median durations } \\
\cline { 2 - 3 } \cline { 5 - 6 } Petitioner & De facto & De jure & & De facto & De jure \\
\hline Male & 8.6 & 13.4 & & 6.9 & $11 \cdot 3$ \\
Female & 9.4 & 13.9 & & $7 \cdot 2$ & $11 \cdot 3$ \\
All & 9.1 & 13.7 & & 7.0 & $11 \cdot 3$ \\
\hline
\end{tabular}


TABle 6. Percentage of successive marriage cohorts divorced by stated legal durations of marriage where wife was under 20 years of age at marriage (source: Registrar General)

\begin{tabular}{|c|c|c|c|c|c|c|c|c|}
\hline \multirow{2}{*}{$\begin{array}{c}\text { Marriage } \\
\text { cohort }\end{array}$} & \multicolumn{8}{|c|}{ Duration of marriage (completed years) } \\
\hline & 3 & 4 & 5 & 6 & 7 & 8 & 9 & 10 \\
\hline $\begin{array}{l}1960 \\
1961 \\
1962 \\
1963 \\
1964 \\
1965 \\
1966 \\
1967\end{array}$ & $\begin{array}{l}0.17 \\
0.20 \\
0.23 \\
0 \cdot 21 \\
0.21 \\
0.28 \\
0.30 \\
0.37^{*}\end{array}$ & $\begin{array}{l}1 \cdot 16 \\
1 \cdot 27 \\
1 \cdot 39 \\
1 \cdot 59 \\
1 \cdot 70 \\
1 \cdot 91 \\
2 \cdot 18^{*}\end{array}$ & $\begin{array}{l}2 \cdot 86 \\
2 \cdot 87 \\
3 \cdot 15 \\
3 \cdot 55 \\
3 \cdot 78 \\
4 \cdot 26^{*}\end{array}$ & $\begin{array}{l}4 \cdot 39 \\
4 \cdot 54 \\
4 \cdot 85 \\
5 \cdot 51 \\
5 \cdot 96^{*}\end{array}$ & $\begin{array}{l}6 \cdot 02 \\
6 \cdot 18 \\
6 \cdot 64 \\
7 \cdot 56 *\end{array}$ & $\begin{array}{l}7 \cdot 56 \\
7 \cdot 88 \\
8 \cdot 49 *\end{array}$ & $\begin{array}{l}9 \cdot 10 \\
9 \cdot 69^{*}\end{array}$ & $10 \cdot 61 *$ \\
\hline
\end{tabular}

* Unofficial figures.

TABLE 7. Percentage of successive marriage cohorts divorced by stated legal duration of marriage where both spouses were under 20 years of age at marriage (source: Registrar General)

\begin{tabular}{cccccccc}
\hline \multirow{2}{*}{$\begin{array}{c}\text { Marriage } \\
\text { cohort }\end{array}$} & 3 & 4 & 5 & 6 & 7 & 8 & 9 \\
\cline { 2 - 7 } & $0 \cdot 19$ & $1 \cdot 79$ & $4 \cdot 37$ & $6 \cdot 57$ & $9 \cdot 04$ & $11 \cdot 16$ & $13 \cdot 33$ \\
1960 & $0 \cdot 20$ & $1 \cdot 77$ & $4 \cdot 16$ & $6 \cdot 66$ & $9 \cdot 03$ & $11 \cdot 31$ & \\
1961 & $0 \cdot 27$ & $1 \cdot 91$ & $4 \cdot 34$ & 6.98 & $9 \cdot 52$ & & \\
1963 & $0 \cdot 22$ & $2 \cdot 16$ & $4 \cdot 96$ & $7 \cdot 89$ & & & \\
1964 & $0 \cdot 22$ & $2 \cdot 27$ & $5 \cdot 12$ & & & & \\
1965 & $0 \cdot 30$ & $2 \cdot 50$ & & & & & \\
1966 & $0 \cdot 30$ & & & & & \\
\hline
\end{tabular}

these figures should be compared with under $5 \%$ for all marriages. Each successive cohort at each successive interval shows an increased incidence, indicating that as measured by this technique young marriages shared in the increasing vulnerability of marriage throughout the decade.

While the positive association between marital instability and youthful marriage is evident, the interpretation to be placed on this is less obvious. Many observers have subscribed to the commonsense explanation that fault lies in the immaturity of the individuals concerned, but this is to oversimplify the issue. Viewed sociologically, the chronological ages of spouses are only significant to the extent that their years adversely affect their competence to play the appropriate marital roles. There are structured differences (e.g. by social class) both in sex-role definition and in the bases of marital satisfaction, and these in any case are subject to historical change. The achievement of maturity has other aspects than the development of firm identity, such as the attainment of economic, sexual and reproductive viability, and the importance of maturity in the personal development sense will partly depend on group-validated assumptions about marital relationships. If these stress traditional breadwinner/housekeeper roles rather than sensitive and fulfilling inter-spousal communication, then mature identity is not such an essential quality for stable marriage. For some American writers (e.g. Winch \& Greer, 1965; Burchinal, 1965) it is likely that where families of origin have both the norms and the resources to support a young couple, then youthful marriage may not be unduly unstable.

The elucidation of the relationship between marriage age and stability is confounded by the fact that there is a constellation of breakdown-disposing factors associated with young marriage, and currently available data do not permit an unravelling of their effects. For instance, Goode (1962) has shown that in Western countries marriage breakdown is inversely related to social class, and this will later be confirmed for Britain. But equally, there are strongly marked social class differentials in age at marriage, with the working class marrying younger than the middle classes (General Register Office, 1965). We might argue, therefore, that there is nothing particularly unstable about young marriages, and that the instability which we apparently observe is an artefact of the over-representation of lowerstrata couples with their higher rates of marital disruption. Conversely, we could argue that there is nothing especially unstable about working class marriages, but that their breakdown experience is conditioned by a propensity to marry young. It is necessary here to conclude with Winch (1971) that at the moment 'no analysis has appeared that would warrant a definite conclusion on this point'. 
There are other complicating factors in this issue, such as the greater propensity for teenage weddings to involve pre-marital pregnancy (Rowntree, 1964b). It has been shown that pre-marital conception is divorce-disposing in the United States (Christensen \& Meissner, 1953), and also that this factor is overrepresented in marriages of very brief duration in this country (Chester, 1972b). Pre-maritally pregnant brides also tend to have briefer engagements than those more prudent, and length of engagement is related to stability of marriage (Goode, 1966). Because of the complexity of these interlocking factors it is not currently possible to measure, or even confidently to assert the existence of, the effect on marital stability of age at marriage per se. This is an important gap in our knowledge. Young marriage is an emotionally charged issue because it touches several important public values, such as premarital chastity, the virtues of strong family life, and the importance of education or occupational training. Because early marriage seems threatening to such values negative views on youthful marriage are widespread, even though the relevance of age as such cannot be clearly shown. Knowledge of the true relationships between the factors enumerated above would clearly be helpful to social analysts and marital practitioners alike.

\section{The sex distribution of divorce petitions}

The distribution of petitions by sex has varied over time, and with present knowledge it is not certain what meaning may be attached to recent patterns. Until now each divorce has required an 'innocent' petitioner and a 'guilty' respondent, and it might therefore be thought that the sex-distribution of petitions might also measure the distribution of matrimonial complaint. While it seems likely that the majority of offences cited are in some sense genuine, however, it cannot necessarily be assumed that the petitioner was the more dissatisfied of the spouses or the first to want a divorce. For instance, one who wants a divorce may use strategies designed to lead a naïve partner to initiate breakup of the marriage. Certainly Goode (1956) concluded that whoever filed suit, it was typically the husband who first wanted a divorce, and it is hoped that field-work currently in hand will shed light on this issue.

Table 8 shows that from the beginning of modern divorce law until 1923 the female share of petitions remained constant at somewhat over $40 \%$, with the exception only of the war-affected years 1916-20. That this distribution was influenced by sexually discriminatory legislation is shown by the sequel of the 1923 reform which equalized petitioning rights. Rising temporarily to over $60 \%$, the female share then settled so that throughout the 1930 s there was a 55:45 female/male ratio, an approximate reversal of the earlier disproportion. The temporarily inflated female figures after 1923 show the 'backlog effect' which characteristically appears when legal or administrative changes make divorce available to previously frustrated aspirant petitioners.

The years immediately after the 1939-45 war repeat the pattern of 1916-20 in showing a sharp rise in the male share of petitions. This pattern is congruent with American experience, and represents the working out of some wartime effects on marriage. Husbands can more readily establish proof of infidelity than can wives, and in the case of the last war, male absence on military or essential duties reduced the opportunity of wives to establish the grounds of desertion and cruelty. By 1950, however, the female share was re-established at the pre-war level, and the ratio 55:45 was maintained till 1959, when a new trend in the distribution began. In every year since then the female share has increased until, in 1970 , it reached $63.7 \%$. English experience is thus moving to resemble that of America, where 75\% of suits are filed by wives (Kephart, 1964), and the trend is difficult to explain in terms of legal or administrative factors related to divorce. The rising female share is coincident in time with the general rise in divorce figures, and doubtless the explanation of both trends must be sought in structural and normative change.

Extensive analysis of the sex distribution of petitions is prohibited by the characteristic dearth of information, but a number of conclusions can be drawn from available data (Chester, 1970). These are that (a) the female share of petitions is high in

TABLE 8. Petitions for dissolution or nullity-percentage filed by wives 1861-1970: England and Wales

\begin{tabular}{llllll}
\hline \multicolumn{1}{c}{ Date } & $\%$ & Date & $\%$ & Date & $\%$ \\
\hline $1861-1900$ & $41 \cdot 3$ & 1940 & $49 \cdot 4$ & 1958 & $54 \cdot 6$ \\
$1901-05$ & $38 \cdot 2$ & $1941-45$ & $46 \cdot 2$ & 1959 & $55 \cdot 0$ \\
$1906-10$ & $44 \cdot 0$ & 1946 & $36 \cdot 7$ & 1960 & $56 \cdot 4$ \\
$1914-15$ & $41 \cdot 8$ & 1947 & $38 \cdot 8$ & $1961-62$ & $57 \cdot 3$ \\
$1916-20$ & $26 \cdot 4$ & 1948 & $50 \cdot 0$ & $1963-64$ & $58 \cdot 7$ \\
$1921-22$ & $43 \cdot 3$ & 1949 & $51 \cdot 2$ & $1965-66$ & $60 \cdot 2$ \\
1923 & $52 \cdot 6$ & 1950 & $54 \cdot 4$ & $1967-68$ & $62 \cdot 5$ \\
1924 & $61 \cdot 6$ & 1951 & $56 \cdot 5$ & $1969-70$ & $63 \cdot 3$ \\
$1925-29$ & $58 \cdot 2$ & $1952-56$ & $55 \cdot 2$ & & \\
$1930-39$ & $54 \cdot 2$ & 1957 & $54 \cdot 2$ & & \\
\hline
\end{tabular}


the case of fertile marriages, and particularly high where there has been pre-marital pregnancy; (b) the sexes differ markedly in their use of grounds for divorce, with adultery $(67 \%)$ and desertion $(30 \%)$ accounting for most male petitions, whereas female petitions were spread more evenly over the three main grounds in the rank order adultery (45\%), cruelty $(31 \%)$ and desertion $(23 \%)$; (c) there has been in recent years a shift towards adultery as a ground for both sexes, at the expense of desertion, while the use of cruelty by women has increased; and (d) the duration of marriage varies relatively little by sex of petitioner, although the marriages of female petitioners seem to have endured marginally longer (see Table 5).

\section{Social class, occupation and divorce}

Social class is among the most commonly-used variables in empirical social studies, so it is perhaps surprising to find that we can say relatively little about the class distribution of divorce or marriage breakdown in Britain. The official statistics do not routinely report on this variable, and did so only between 1896 and 1921. There is, however, a scattering of information which makes it possible to assert a few broad propositions about the recent situation with some confidence. The sources are:

(a) a comparison of the distribution by occupational class of the divorce populations of 1871 and 1951 (Rowntree \& Carrier, 1958);

(b) data on seventy-nine divorce cases drawn in a national marriage sample (Rowntree, 1964a);

(c) some analysis of a sample of the divorces of 1961 (McGregor et al., 1970);

(d) some analysis of a sample of the divorces of 1966 (General Register Office, 1966).

There are certain difficulties in marshalling even this limited range of material, because the items use differing bases of classification and attempt differing tasks. Item (a) for instance, uses collapsed categories based on the Registrar General's socio-economic groups, while items (c) and (d) use the Registrar General's five class system, and item (b) collapses the cases into the categories manual and non-manual. Further, item (a) compares the class distribution of divorce for two different years, and also compares the 1951 divorce population with the same year's census population, item (c) compares 1961 divorces with the same year's census population, item (d) compares 1966 divorces with the 1961 census figures, and item (b) calculates the proportion of different class groups which had parted by the time of the study. These differences should be borne in mind.

It is a common popular belief that divorce is primarily a middle-class prerogative, and that the poor man's divorce is separation (or desertion). This belief accords neither with American experience (e.g. Udry, 1966-67), nor with cross-national analysis of rates of marital instability (Goode, 1962). Goode $(1962,1966)$ suggests theoretical reasons for supposing that there will typically be more instability towards the lower strata than towards the upper, although whether such tendencies are manifested in divorce rates obviously depends upon how extensively available the divorce remedy is. Family law in Western countries has characteristically set out to solve the matrimonial problems of the upper and middle classes, and it might be expected that higher status groups would have higher divorce rates in nineteenth century Britain. Rowntree \& Carrier show that in 1871 manual workers formed only $17 \%$ of the divorcing population, and even this figure might perhaps be thought surprisingly high in view of the legal and economic barriers to divorce which then faced the working class. Figures provided to the 1909 Royal Commission on Divorce and Matrimonial Causes suggested that by then the proportion of divorces going to manual workers was approaching $30 \%$, and the restructuring of the divorce population which this indicated has continued since. Rowntree \& Carrier concluded that by 1951 couples in the various broad occupational categories were divorcing to much the same extent, although the authors were uncertain whether this was an ultimate situation, a temporary phenomenon due to the introduction of legal aid and due for reversal, or a stage in a long-run trend towards the American pattern. Manual workers, on their classification, accounted for $70 \%$ of both the divorcing and the remaining married populations in 1951, while professional men and managers accounted for $14 \%$ of each group. It now seems likely that since 1951 manual workers have moved beyond parity. McGregor et al., using a different classification, showed that manual occupations were followed by $79 \%$ of males in the still-married population and $83 \%$ in the divorcing population in 1961 . Unfortunately these authors do not reveal the disposition of cases where occupation was unstated, or of those where the husband was in the armed forces, and so comparison with the 1966 official statistics is difficult. In the latter, $72 \%$ of those divorcing were classified as manual workers, and a further $16 \%$ were in the armed services. Since the majority of the latter were probably non-commissioned, it seems likely, in conjunction with the findings of McGregor et al., that more than $80 \%$ of divorces now occur in marriages where the husband would rank below Social Classes I and II in the Registrar General's scale. Within this fraction there is evident a particular over-representation of Class V, unskilled workers.

At some uncertain, but relatively recent point, then, the working class seems to have surpassed the higher status groups in contribution to divorce. 
Probably working-class marriages have always been the more unstable, but the earlier barriers prevented this from being manifest in the divorce statistics, and it is from this earlier period that the notion survives that divorce is primarily a middle-class phenomenon. The liberalization of divorce law and procedures and the provision of legal aid, together with economic and social changes of a more fundamental kind, have more recently afforded opportunity for working-class marital difficulties to be expressed in divorce. Despite the unsatisfactory nature of the data, there can be little doubt that marital instability, as measured by termination, is inversely related to social rank. In addition to the divorce figures, those who use the magistrates' matrimonial jurisdiction are almost invariably working-class, as are the vast majority of wives without court orders who depend upon social security benefits for income. It seems safe to assert that social class, through its patterning of relationships, expectations and behaviour exerts influence on marital satisfaction and stability, with the outcome adumbrated above.

It should not be lost sight of that gross indicators, such as the social classes, may obscure differences in propensity to divorce associated with particular occupations or types of work situation. One observer (Noble, 1970) has gone so far as to deny the class relationship asserted above, claiming that divorce varies not so much with the status of occupations as with aspects of work experience which they imply. Noble argues that the higher-risk occupations are those which create economic insecurity or certain other kinds of strain. This argument is based on census data, however, and because it ignores such matters as re-marriage rates, these data are defective for the kind of analysis involved. Noble's argument is most effectively countered by Gibson (1971), who firmly concludes that the relationship between class and instability is an inverse one. It may well be that particular occupations, such as 'roving' occupations, the armed forces, and those jobs which create ready opportunity for inter-sexual encounters, contribute over-extensively to divorce. Except that the armed services seem rather strongly over-represented, we have not sufficient data to do more than speculate on this issue. In any case, even if such relationships were found, it would still be necessary to analyse whether the association was causal or correlative of some personal characteristics, because selective factors might recruit for both particular occupations and divorce. Such refinements of analysis must wait upon further research.

\section{Fertility and marriage breakdown}

A popular belief which receives general assent in the professional literature is the notion that childless marriages are more prone to divorce than are fertile unions. It is commonly remarked that infertile couples appear more commonly among these divorcing than among those remaining married, and inferred from this that there is either a causal or a mediated relationship between infertility and marriage breakdown. This relationship has been tentatively denied for the U.S.A. (Monahan, 1955), and an analysis currently in hand provisionally suggests that in this country also the relationship which has been noted is principally an artefact of statistical and reporting procedures. It should be noted that 'infertility' here is used after the manner of British demographers to refer to reproductive performance rather than reproductive potential. The different usage of the term by bio-medical workers is an occasional cause of confusion (Hawthorn, 1970).

It is helpful to begin with some data on the proportion of divorces which concern childless couples. In $1871,38 \%$ of divorcing women were without children, and this at a time when infertility was rare. Comparisons over the past century, however, are confounded by the very great changes in fertility patterns during the past few generations, and it will be profitable to concentrate on more recent marriages. Table 9 gives details of dissolved marriages, proportion childless, and numbers of children affected for various years since 1951, and it will be seen that the proportion of infertile couples in the divorcing population has been falling of late. It is important to note, however, that the numbers of 'children' shown in column $\mathbf{3}$ are deceptive in various ways. To begin with, this number relates to surviving 'children of the family', a legal concept. Consequently, some of those included were not born to the couple, and the table does not offer a complete fertility record because it omits any children who have died. The latter point is important when comparison is made with those remaining married, because the census data used for the comparison measures all fertility experience for the still-married group, irrespective of survival. Furthermore, many of the 'children' recorded in the table are in fact mature adults. In view of the frequently expressed concern about the effects of divorce, it is a surprising

TABLE 9. Divorce and nullity decrees made absolute, percentage of these with no children, and total numbers of children affected by the decrees, various years: England and Wales (source: Registrar General)

\begin{tabular}{cccc}
\hline Year & Decrees & $\%$ childless & Total children \\
\hline 1951 & 28,767 & 34 & $35,000^{*}$ \\
1956 & 26,265 & 34 & $32,500^{*}$ \\
1961 & 25,394 & 32 & 34,820 \\
1966 & 39,067 & 28 & 59,591 \\
1969 & 51,310 & 27 & 81,106 \\
\hline
\end{tabular}

* approx. 
fact that we cannot derive from official statistics an account of minor children affected by divorce. However, by reworking some data provided by Gibson (1970) it is possible to suggest a figure of 0.9 children under school-leaving age per divorce. This would mean that in 1969 approximately 55,000 of the 81,000 children shown were actually young enough to be of concern. Clearly, large numbers of young people are affected by divorce each year, even though a high proportion of divorces concern couples who are either childless or have only mature children.

The most important point to be made in connection with childlessness and divorce, however, is that commentators in this country have largely ignored the significance of duration of marriage. Fertility tables are normally constructed on the assumption that married women experience constant exposure to pregnancy risk throughout their reproductive period, and duration is allowed for when comparisons are made. When the Registrar General makes his comparisons between the fertility of divorcing and non-divorcing couples, he does not ignore the duration factor, but the duration he uses for divorcees is the legal length of marriage. From the evidence presented earlier it will be evident that de jure duration significantly exaggerates opportunity to conceive, and that a better statement of this opportunity is provided by the de facto duration. Preliminary results suggest that when de facto duration is substituted for de jure the fertility differential effectively disappears. Thus, although the official commentary shows that in 1964 the proportion infertile was $30 \%$ amongst divorcing wives and $18 \%$ among census wives, with duration constant, this gives a misleading account of the true relativities. Confidence in this preliminary suggestion is increased by the fact that McGregor et al. (1970) found that amongst their magistrates' court sample (for whom duration would be roughly equivalent to de facto duration as described above) fertility did not differ from that of the census population. It is not unreasonable to suppose, therefore, that most of the alleged association between childlessness and divorce derives from inappropriate comparison, and that the various explanations of the relationship which have been offered are seeking to explain something which is non-existent. It would be interesting to explore the ways in which belief in the relationship, by associating marital pathology with abstention from parenthood, is supportive of traditional family ideology and values. Meanwhile, we can conclude with Monahan (1955) that in fact marital stability may not be at all related to fertility, and such a conclusion would be consistent with the general failure of research to find that children and marital happiness are causally related (Hicks \& Platt, 1970).

\section{Conclusion}

In the analysis of marital breakdown in Britain the most persistent problem is the inadequacy of the available data. Our information is unsatisfactory both in volume and range, particularly by contrast with that available for the U.S.A. To the limitations of the official statistics must be added the dearth of social scientific investigation, and the resulting lacunae might perhaps be thought curious in view of the importance accorded to stable marriage in our society and of the individual and social costs of marriage breakdown. The discussion above briefly annotates current information on volume, and on the broad variables of duration, age at marriage, sex, social class, and fertility, but these do not exhaust even the major heuristic categories which might be helpful for epidemiological or causal analysis. Other major variables for which data exist in America include urban/rural differentiation, ethnicity, religious affiliation, education, income, and remarriage.

Of these possibilities it is true that some may be of only marginal or very recent relevance to this country. For instance, in a country the size of Britain meaningful distinction between urban and rural is hard to make in the wake of modern developments in transport, the distribution of population, and the mass media. Again, it is only recently that immigration from non-European societies has become a relevant factor in the study of marriage breakdown, and differential recording of the immigrant population is fraught with political and other difficulties, as the recent census showed. Nevertheless, it might be expected that information based on the ethnic variable would be increasingly helpful, since the patterns and meanings of marriage breakdown may be quite different for different culture groups. On religious affiliation our knowledge is very slim indeed. The single (and brief) official commentary on this had perforce to be based on the dubiously valid criterion of mode of solemnization of the marriage. This criterion is relatively unhelpful because type of ceremony is associated with such confounding variables as premarital pregnancy and age at marriage (General Register Office, 1966). Of the effects of education and income we are totally ignorant, except in so far as these are implied in an undifferentiated manner by occupational class, and as noted above detailed knowledge of the class variable itself is not currently available.

On remarriage there is information of a usable kind. Space limitations preclude full analysis, but data on two aspects of remarriage may be briefly noted. Where remarriage is subsequent to divorce it is probable that unions are less stable than primary marriages; and where termination derives from remarriage situations, it does so at characteristically 
briefer durations (General Register Office, 1966; Chester, 1971a). Data from America and other societies support these inferences, and correspond with British information also in showing very high remarriage rates for those who divorce. This is particularly so for divorced men, and since these tend to marry single girls they are in competition with bachelors for the available pool of nubile spinsters. Where divorce is relatively common and remarriage rates high, the divorce system can be conceptualized as in effect part of the general system of courtship and marriage. It becomes, that is, part of the assortative process whereby individuals locate suitable spouses, and the term serial monogamy has been coined to depict the situation where significant numbers of people have a plurality of spouses in consecutive sequence. To the extent that companionate marriage becomes a culture-wide ideal, and therefore that the personal tie between husband and wife becomes the crucial element in the definition of successful marriage, there may be arguments for people being free to change spouses when appropriate in order to maximize personal satisfactions. This is to ignore potential effects of divorce on third parties, particularly any immature children there may be, but stability of the family system is quite compatible sociologically with high rates of marital disintegration. Certainly it is not clear that all therapeutic intervention should concentrate on the prevention of breakup to the exclusion of action to minimize any individually disruptive consequences there may be when breakup does occur (Chester, 1971c). Ideological and historical factors militate against a ready acceptance of divorce, but it may be that restrictive approaches are counter-productive where the interventionist objective is the strengthening of family life rather than the preservation of culturally preferred moral codes.

In the study of marriage breakdown much more remains to be done than has so far been achieved. Some part of the necessary knowledge can, and should, some from sociology, but contribution is equally necessary from such fields as psychological medicine, social work, and the law. Statistical exegesis needs to be supplemented by field surveys and clinical studies, and indeed by any other method which would shed light on this mass phenomenon of our time. Certainly for the foreseeable future there will be no shortage of openings for any who wish to enter this field in a research capacity.

\section{Acknowledgments}

The work upon which this paper depends has been financially supported by the Eugenics Society, the Social Science Research Council, and the Department of Health and Social Security, to whom my thanks are due. I am grateful also to Miss S. Hirst of the D.H.S.S. for the provision of information about supplementary benefit recipients since
1966; and to Mr O. Adegboyega and Mr J. Craig of the Office of Population Censuses and Surveys for the provision of as yet unpublished data relating to divorce in 1970. The research assistant to my field project is Miss J. Streather, whom I thank for critical comment.

\section{References}

Burchinal, L.G. (1965) Trends and prospects for young marriages in the United States. Journal of Marriage and the Family, 27, 243.

Chesser, E. (1956) The Sexual, Marital and Family Relationships of the English Woman. Hutchinson's Medical Publications, London.

Chester, R. (1970) Sex differences in divorce behaviour. Journal of Biosocial Science, Suppl. 2, 121.

Chester, R. (1971a) The duration of marriage to divorce. British Journal of Sociology, 22, 172.

Chester, R. (1971b) Contemporary trends in the stability of English marriage. Journal of Biosocial Science, 3, 389.

Chester, R. (1971c) Health and marriage breakdown: experience of a sample of divorced women. British Journal of Preventive and Social Medicine, 25, 231.

Chester, R. (1972a) Divorce and legal aid: a false hypothesis. Sociology, 6, 205.

Chester, R. (1972b) Some characteristics of marriages of brief duration. Medical Gynaecology and Sociology, 6, 9.

Christensen, H.T. \& Meissner, H.H. (1953) Studies in child spacing: III-premarital pregnancy as a factor in divorce. American Sociological Review, 18, 641.

FERRIS, A.L. (1970) An indicator of marriage dissolution by marriage cohort. Journal of Social Forces, 48, 356.

FLETCHER, R. (1966) The Family and Marriage in Britain. Penguin Books, Harmondsworth.

General Register OfFice (Annual) The Registrar General's Statistical Review of England and Wales. H.M.S.O., London.

Gibson, C. (1970) The case for state insurance against broken marriages. Social Work Today, 1, 25.

Gibson, C. (1971) A note on family breakdown in England and Wales. British Journal of Sociology, 22, 322.

Goode, W.J. (1956) After Divorce. The Free Press, New York.

Goode, W.J. (1962) Marital satisfaction and stability: a cross-cultural class analysis of divorce rates. International Social Science Journal, 14, 507.

Goode, W.J. (1966) Family disorganization. In: Contemporary Social Problems (Ed. by R. K. Merton and R. A. Nisbet). Harcourt Brace and World, New York.

Hawthorn, G. (1970) The Sociology of Fertility. CollierMacMillan, London.

Hicks, M.W. \& Platt, M. (1970) Marital happiness and stability: A review of research in the sixties. Journal of Marriage and the Family, 32, 553.

KEPHART, W.M. (1964) Legal and procedural aspects of marriage and divorce. In: Handbook of Marriage and the Family (Ed. by H. T. Christensen). Rand McNally, Chicago.

MCGregor, O.R. (1957) Divorce in England. Heinemann, London.

McGregor, O.R., Blom-Cooper, L. \& Gibson, C. (1970) Separated Spouses. Duckworth, London.

Monahan, T.P. (1955) Is childlessness related to family stability? American Sociological Review, 20, 446.

MonAHAN, T.P. (1962) When married couples part: statistical trends and relationships in divorce. American Sociological Review, $27,625$.

Moss, J.J. (1955) Teenage marriage: cross-national trends and sociological factors in the decision when to marry. Acta Sociologica, 8, 98. 
Murray-Parkes, C. (1971) Psycho-social transitions: a field for study. Social Science and Medicine, 5, 101.

National Assistance Board (Annual to 1965) Report. H.M.S.O., London.

Noble, T. (1970) Family breakdown and social networks. British Journal of Sociology, 21, 135.

Pierce, R. (1963) Marriage in the fifties. Sociological Review, 11 N.S., 215.

Rowntree, G. (1964a) Some aspects of marriage breakdown in Britain during the last 30 years. Population Studies, 18, 147.

Rowntree, G. (1964b) New facts on teenage marriage. New Society, 1, 12 .
Rowntree, G. \& CARrier, N. (1958) The resort to divorce in England and Wales 1858-1957. Population Studies, 11, 188.

RYDER, N.B. (1965) The cohort as a concept in the study of social change. American Sociological Review, 30, 843.

TURner, C. (1969) Family and Kinship in Modern Britain. Routledge and Kegan Paul, London.

UDRY, J.R. (1966-67) Marital instability by race, sex, education and occupation using 1960 census data. American Journal of Sociology, 72, 203.

WINCH, R.F. (1971) The Modern Family, 3rd edn. Holt, Rinehart, Winston, New York.

Winch, R.F. \& Greer, S. (1965) The uncertain relation between early marriage and marital stability: a quest for relevant data. Acta Sociologica, 8, 83. 